\title{
The Rehabilitation of Structures on the National Route 10 Section 12 between Upington Km 0.0 and Nakop Km134.17
}

\author{
Tiago Massingue ${ }^{1 *}$ and Bennie Zietsman ${ }^{2}$ \\ 1 The South African National Roads Agency SOC Ltd, Cape Town, South Africa \\ ${ }^{2}$ Element Consulting Engineers, Cape Town, South Africa
}

\begin{abstract}
National Route 10 Section 12 is situated between Upington and Nakop at the border between South Africa and Namibia in the Northern Cape Province. As part of SANRAL's Bridge Management System, three bridges and twenty four major in-situ cast culverts were identified to be in need of rehabilitation and/or strengthening. This paper details the condition of the existing structures as well as the methods and materials used to repair and strengthen the structures to be in a safe and serviceable condition. Due to the harsh environmental conditions, as well as the remoteness of the structures, the methods and materials for repair had to be carefully considered. In this regard, special reference is made to the use of carbon fibre strips to increase the bearing capacity of the bridge- and culvert deck slabs. The method for the strengthening of the floor slabs and internal walls of a number of culverts, for which the compressive strength of the existing concrete was found to be in the order of $1.0 \mathrm{MPa}$, is also discussed.
\end{abstract}

\section{Background}

The South African National Roads Agency SOC Limited (SANRAL) is mandated to develop, maintain and to manage all assets associated with the South Africa's national roads network. These assets include bridges and structures of the primary network.

In order to effectively manage the bridges and structures, SANRAL has a Bridge Management System where all bridges and major culverts are regularly inspected on a five year basis by accredited bridge inspectors.

During such inspections SANRAL identified the need to rehabilitate and strengthen three bridges and twentyfour major culverts on National Route 10 Section 12 between Upington ( $\mathrm{Km} \mathrm{0.00)}$ and Nakop (Km 134.17). The following project milestones were undertaken to address these identified problems:

- To conduct the necessary detailed condition assessment and investigations;

- To present the results from such investigations as well as proposed remedial actions in an assessment and preliminary design report;

- To perform the detailed design, prepare the necessary design drawings and to include the design parameters in a detail design report.

\section{Description of the Project}

National Route 10 Section 12 is the road between Upington and the border between South Africa and the Namibian border post of Nakop in the Northern Cape Province. Nakop is approximately $140 \mathrm{~km}$ west-northwest of Upington.
The road, including the structures, was constructed in the early seventies, resulting in all structures being older than forty years.

The full length of the road is situated in a dry, semidesert climatic region with very high daytime temperatures during the summer and low night time temperatures during the winter. The terrain can generally be classified as flat with isolated areas where it can be classified as rolling.

The road is a classified as Class 2 road with a low traffic intensity. Although the volume of traffic on the road is low, it serves as an important link between Windhoek, the capital of Namibia, and the Witwatersrand, which is the financial hub of South Africa.

\section{Methodology}

The visual assessment and investigation was done in January 2015. Weather conditions in such period was described as very hot with temperatures exceeding $40^{\circ} \mathrm{C}$.

The team performing the visual assessment was lead by an accredited SANRAL Bridge Inspector. The assessment was done in accordance to the STRUMAN Bridge Management System (BMS) defects based system using the Degree-Extent-Relevance (DER) rating method, together with general structural engineering principles.

\section{Condition of Existing Structures}

The condition of the existing structures can be summarized as follows: 


\subsection{Bridges}

\subsubsection{B4752_1 Molopo Bridge 1 (Km 67.02)}

This is a 4-span, $24.0 \mathrm{~m}$ long bridge of continuous box construction with no joints, spanning the eastern Molopo River branch. It was built in 1972. The following defects were found:

- Extensive alkali-silica reaction on the unpaved portions of the deck;

- Minor spalling of the bottom of the parapets;

- Extensive cracking in deck soffits $(0.8-1.0 \mathrm{~mm}$ wide);

- Blocked scuppers and weep holes;

The sagging cracking was regarded to be serious with a DER rating of 344.

There was no evidence of hogging cracking.

A note written on the soffit of the third span indicated that a crack of $1.2 \mathrm{~mm}$ wide was measured on 25 April 1983. The same crack was measured during this inspection and it was found to be approximately $0.8 \mathrm{~mm}$ wide. As stated previously, the current inspection was conducted during very hot conditions, which means that the concrete may have expanded, closing the crack slightly. Whatever the reason, this is an indication that the cracking did not worsen considerably during the past 34 years. The situation was therefore not regarded to be dangerous, but strengthening was clearly required.

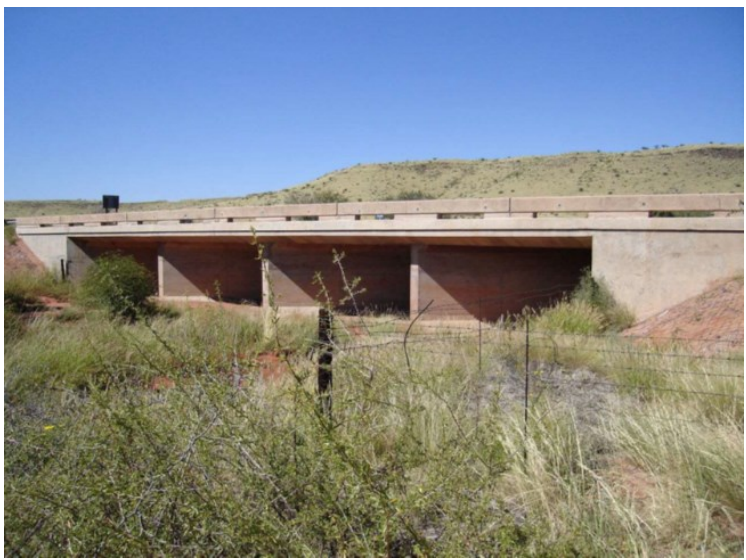

Figure 1: B4752_1 Molopo Bridge 1 (Km 67.02)

A similar bridge in the area also built in the early 1970's, was demolished and had been recently reconstructed. When it was demolished, it was observed that there was very little bond between the reinforcing and the concrete. The old reinforcing was "twist-hardened" and it is thought that it "twisted back" towards its previous un-twisted state shortly after the concrete was casted, thereby causing the poor bond between the reinforcing and the concrete. This poor bond was also determined to be the reason for the deterioration of the bridge.

It is thought that this may also be the reason for the formation of the sagging cracks at the Molopo bridges. According to the as-built drawings of the bride, the deck is $380 \mathrm{~mm}$ thick, spanning $6.0 \mathrm{~m}$ and reinforced with Y25 at $125 \mathrm{~mm} \mathrm{c} / \mathrm{c}$. This design should not have yielded at the current traffic loading. Under the current NC30 loading the maximum sagging design moment is approximately
$130 \mathrm{kNm} / \mathrm{m}$ whereas the capacity should be approximately $320 \mathrm{kNm} / \mathrm{m}$, even with R-steel.

Evidence of propping was also found at the bridge. Old epoxy against the soffits and markings on the bottom slab indicate that the propping may have been done when the sagging cracks were first detected. A second set of much younger propping markings have also been found. This was most probably done by abnormal load transporters.

\subsubsection{B4752_2 Molopo Bridge $2(\mathrm{Km} 67.11)$}

This is a 6-span, $36.0 \mathrm{~m}$ long bridge of continuous box construction in two 3-cell sections with an expansion joint between the cells. It spans the second eastern Molopo River branch and was also constructed in 1972. The following defects were found:

- Extensive alkali-silica reaction on the unpaved portions of the deck;

- The centre joint has failed with water and rubble entering the space between the cells;

- Minor spalling of the bottom of the parapets;

- Cracking and spalling at the top of south abutment wall as well as acute corner of S1 deck edge due to possible uplift action resulting from the $45^{\circ}$ skew;

- Extensive cracking in deck soffits $(0.8-1.0 \mathrm{~mm}$ wide);

- Blocked scuppers and weep holes;

- Horizontal crack at the top of pier P4 that was previously repaired;

- Exposed reinforcement at bottom of P1;

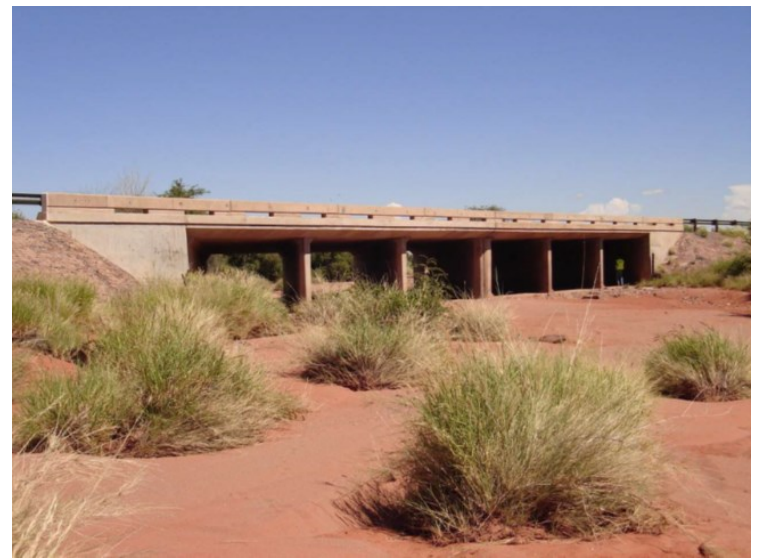

Figure 2: B4752_2 Molopo Bridge 2 (Km 67.11)

The sagging cracking for this bridge was also regarded to be serious with a DER rating of 344 . There was no evidence of hogging cracking.

The same arguments regarding the possible cause and history behind the sagging cracks made for Bridge B4752 1, applies.

\subsubsection{B4751 Molopo Bridge 3 ( $K m$ 72.60)}

This is a 9-span, $54.0 \mathrm{~m}$ long bridge of continuous box construction in three 3-cell sections with expansion joints between the sections. The bridges span the vlei-like main 
western Molopo River branch and was also constructed in 1972. Unlike the previous two bridges, this bridge has rather high abutments/piers of $5.8 \mathrm{~m}$. The following defects were found:

- Extensive crazing cracking on the unpaved surfaces of the deck and parapets;

- The two joints have failed with water and rubble entering the spaces between the cells;

- Minor spalling of the bottom of the parapets;

- Spalling at pier edges;

- Extensive cracking in deck soffits $(0.6-0.8 \mathrm{~mm}$ wide);

- Blocked scuppers and weep holes;

- Horizontal cracks around P3;

- Serious cracking and crushing at the centre of the bottom slab underneath $\mathrm{S} 1$;

- Minor spalling at the south-western wing wall;

- Rebar corrosion due to insufficient cover at some piers;

- Large spalling crack at the edge of P6;

The sagging cracking for this bridge was also regarded to be serious with a DER rating of 344 . There was no evidence of hogging cracking. The same arguments regarding the possible cause and history behind the sagging cracks made for Bridges B4752_1 and B4752_2, applies.

The cracking and crush-like damage at the bottom slab had to be repaired by strengthening the bottom slabs with a reinforced concrete overlay.

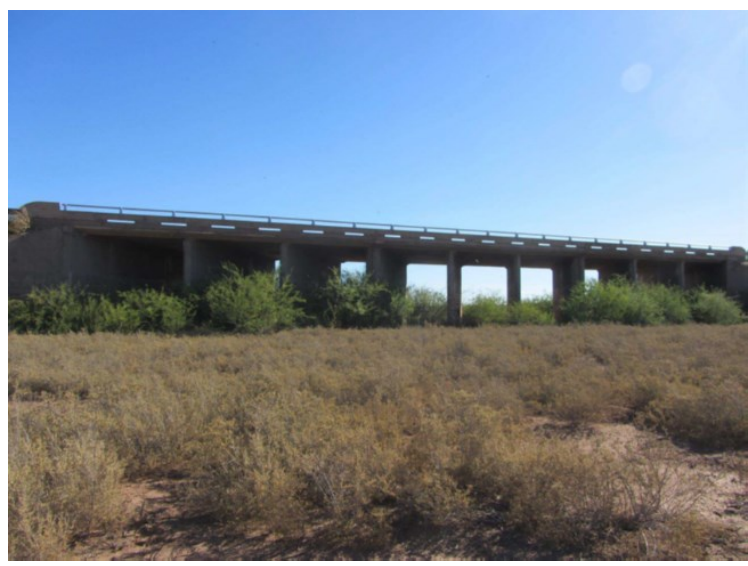

Figure 3: B4751 Molopo Bridge 3 (Km 72.60)

The piers are quite slender due to their height and it was initially assumed that they may experience some torsional forces due to the $35^{\circ}$ skew of the deck and the resulting asymmetrical moments. It is thought that the piers may not have been designed properly for this force as the height of the bridge on the original design drawings is much less than what was eventually constructed and that the reinforcing for the lower bridge was probably just extended to provide for the extended height of the actual piers constructed.

In order to determine the effect of the torsional forces, a detailed three-dimensional frame analysis was carried out using the Prokon Structural Analysis Software. The software was used to model and evaluate the effects of the relatively slender piers with the objective of determining whether they require possible strengthening. The detailed structural analysis was carried out in accordance with the recommendations made in Technical Recommendations for Highways 7 (TMH7) and the load conditions included NA, NB36 and NC loading.

The three-dimensional analysis was carried out using quadrilateral shell elements using the dimensions shown on the as-built drawings and those obtained on site. To obtain the moments and reinforcement required, the TMH7 loading approach was followed. The following assumptions were made:

- Reinforcement cover is $40 \mathrm{~mm}$ thick;

- A single 3-span box structure with $25 \mathrm{MPa}$ concrete has been analysed in isolation, being separated by an expansion joint with a compressible joint filler;

- The supporting stratum was assumed to be rock fill with a stiffness of $30000 \mathrm{kN} / \mathrm{m}^{3}$;

- With a shell size of $400 \times 400 \mathrm{~mm}$ on average a vertical spring support at each shell node with a stiffness of $4800 \mathrm{kN} / \mathrm{m}$ was used as per above assumption;

- The vertical loading was applied as stipulated in TMH 7. The NC30 load was considered critical, applied to the deck using pattern loading (various load cases) to obtain the most adverse effects;

- The bridge location is on a straight road portion, therefore centrifugal loads are non-existing, but horizontal braking actions have been considered as required. $20 \%$ of the NB36 load case was taken into consideration in determining the horizontal force;

- Earth retaining forces have been ignored, as the abutments do not show signs of cracking and/or failure;

- All load factors as prescribed in the code have been used.

From the analysis it was found that the critical pier bending moment envelope was $85 \mathrm{kNm}$, corresponding to a reinforcement requirement of $570 \mathrm{~mm}^{2} / \mathrm{m}$ (Y-steel) or $1030 \mathrm{~mm}^{2} / \mathrm{m}$ (R-steel).

According to the as-built drawings it can be concluded that the reinforcement provided in the piers are R25 at 125 $\mathrm{mm} \mathrm{c} / \mathrm{c}$ resulting in $3928 \mathrm{~mm}^{2} / \mathrm{m}$. From this result it can thus be concluded that the existing steel satisfies the TMH7 design requirement and the pier strength is regarded to be sufficient.

The Prokon model is shown below with only one of the various load combinations used. 


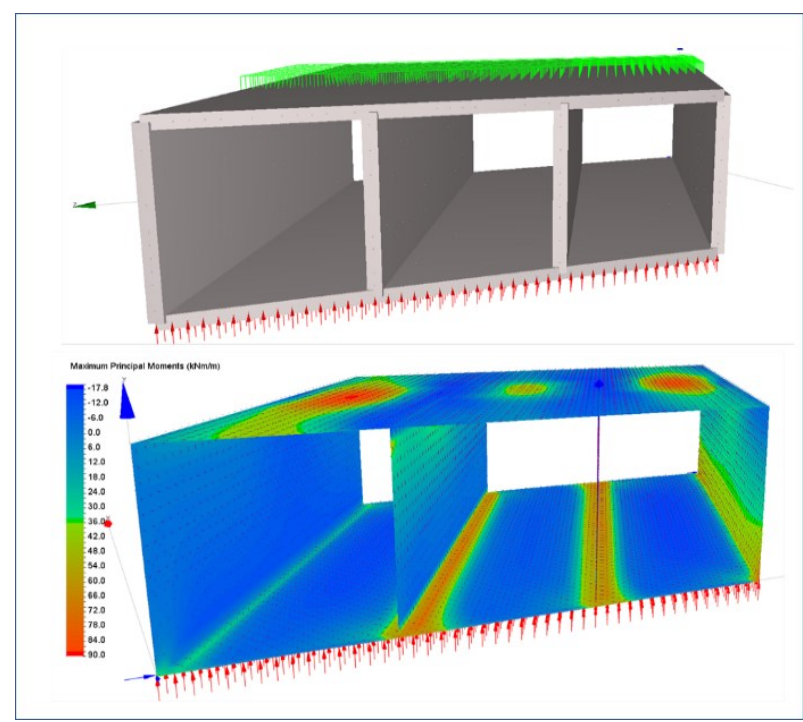

Figure 4: Prokon Structural Model

\subsection{Major Culverts}

Of the 101 major culverts constructed along National Road 10 Section 12, 24 structures were identified from the information provided in the Bridge Management System to be in need of repairs and/or strengthening. These structures were visually assessed and the general defects noted at most or all of the structures can be summarized as follows:

- Top section of wing walls breaking off due to lack of reinforcing;

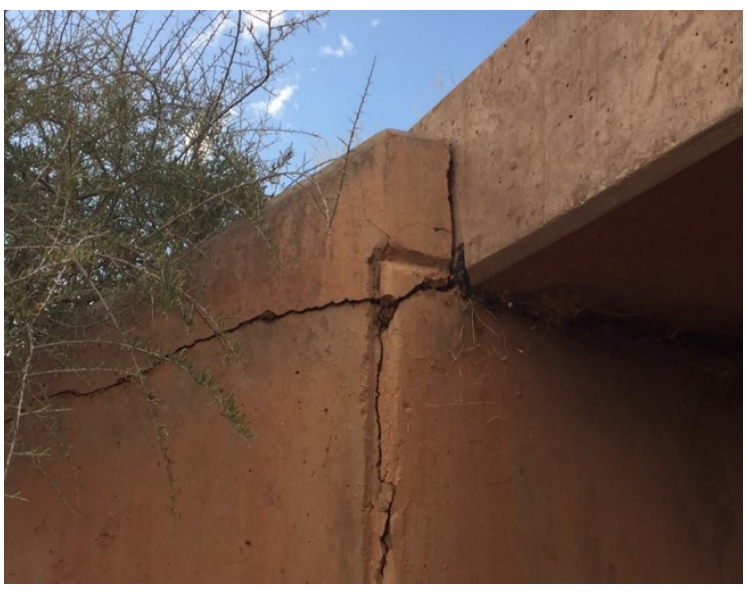

Figure 5: Top Section of Wing Wall Breaking Off

- Vertical cracks in the abutment walls and piers of some culverts;

- Spalling in various structural members, exposing reenforcing steel;

- Severe deterioration and disintegration at a number of culverts of abutment and/or pier concrete (DER 444) with the concrete strength $<1 \mathrm{MPa}$;

- Horizontal cracks in the abutment walls of some culverts, indicating moment failure;

- Missing or damaged apron slabs;

- Extensive cracking in deck soffits of some culverts;

- Extensive cracking in floor slabs of some culverts.

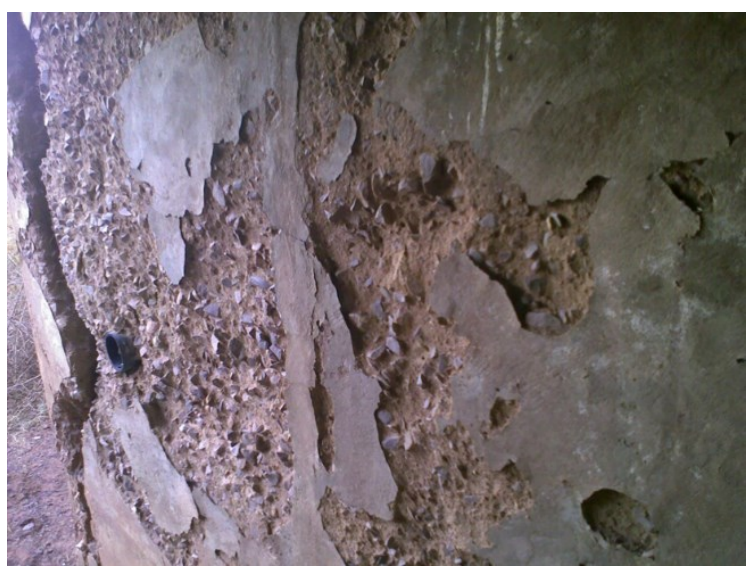

Figure 6: Severe Deterioration of Concrete

\section{Remedial Measures}

All remedial measures were designed to allow for full NA, NB36 and NC30 loading as per the TMH7 code.

Due to the remoteness of the structures and the harsh environmental conditions, the materials and construction methods specified focussed on ease of transport and use. In this regard the use of carbon fibre strips to improve the bearing capacity of the bridge decks proved to be invaluable. The strips are small, light and easy to install.

\subsection{Bridges}

The remedial measures to the three bridges can be summarized as follows:

- Strengthening of deck sections using carbon fibre strips;

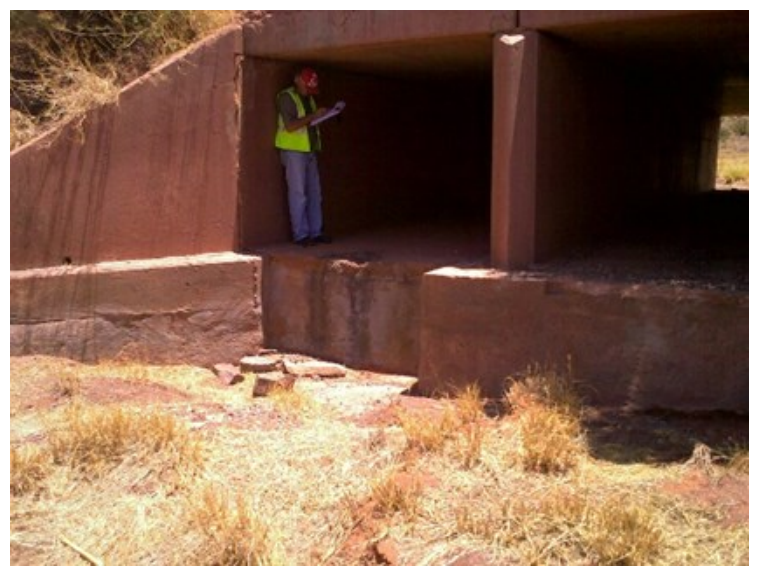

Figure 7: Missing Apron Slab

- Strengthening of floor slabs by concrete overlay;

- Cleaning and re-sealing of joints using highway silicon joint sealant;

- The repair of spalling and cracks;

- The application of a protective silane coating to deteriorating and crazing cracking affected concrete surfaces;

- The clearing of blocked scuppers and weep holes;

- The cleaning of the structures using low-pressure water jetting. 
The quality of the concrete was determined/confirmed by means of core drilling and sample testing. The core specimens were tested as per SANS 5865 method. A total of six cores per bridge structure was taken through the full deck thickness at quarter spans. The aim of the testing was to ensure that carbon fibre strip de-bonding would not occur and to confirm the concrete quality and durability. The results of the tests indicated that de-bonding of the strips would not occur and that the quality of the concrete is acceptable.

\subsubsection{Strengthening of Deck Slabs}

In order to mitigate the sagging cracking noted in the bridge decks, carbon fibre strips were attached to the soffit of the decks in accordance with the following methodology:

- Clean the slab soffits and pier surfaces of all dirt, with low-intensity water jetting;

- Prop the $6.0 \mathrm{~m}$ span decks at centre span position every $1.5 \mathrm{~m}$ using adjustable props with forcemeasurement equipment, applying the force equal to the larger of twice the dead load or the dead load plus $50 \%$ of the NC30 live load on the deck;

- Prepare soffit surface by scabbling and water jet cleaning strips at $500 \mathrm{~mm}$ centres to receive epoxy adhesive compound for carbon fibre strips;

- Apply proprietary epoxy adhesive compound and $50 \mathrm{x}$ $1.2 \mathrm{~mm}$ carbon fibre with minimum $2800 \mathrm{MPa}$ tensile strength plates to the manufacturer's specifications;

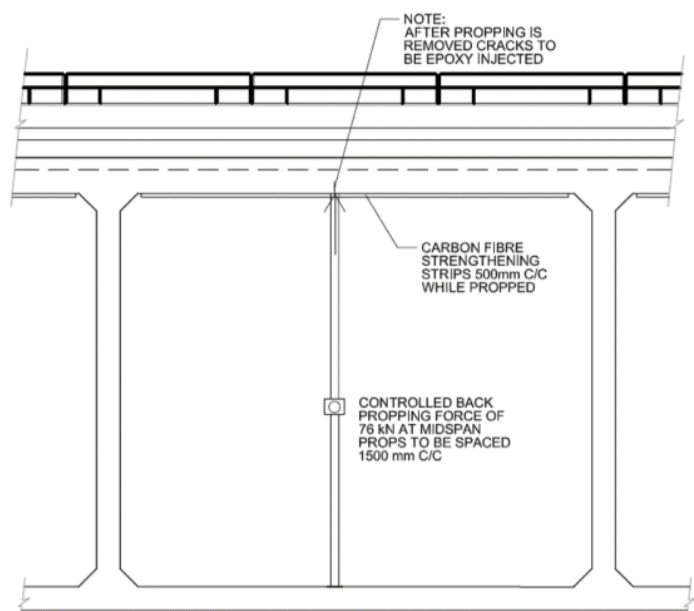

Figure 8: Propping of Bridge Decks for Attaching Carbon Fibre Strips

- After epoxy has cured and hardened in accordance to the manufacturer's specifications, remove props;

- Epoxy crack-inject and seal all visible cracks larger than $0.5 \mathrm{~mm}$;

- Check and monitor all injected cracks for any changes. Where possible, crack sealing was done during the winter when the cracks were at their largest.

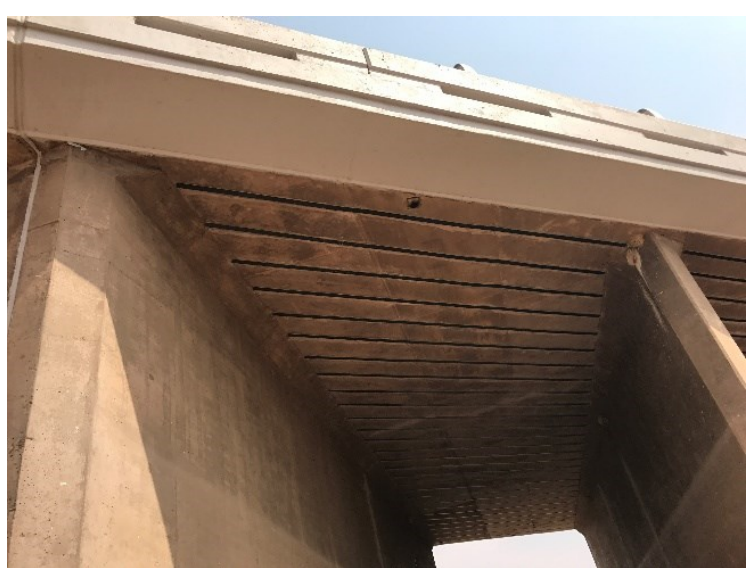

Figure 9: Carbon Fibre Strips Installed at Bridge B4751

\subsubsection{Strengthening of Floor Slabs}

To strengthen the box construction of the bridges which was compromised by the sagging failure, the bottom floor slabs were strengthened by adding a $230 \mathrm{~mm}$ thick reinforced concrete overlay using the following methodology:

- Clean the floor slab of all dirt, bird and insect nests with low-intensity water jetting to provide contamination free surfaces;

- Scabble the whole floor slab to obtain a rough surface and clean all loose material using high pressure waterjetting;

- Drill $12 \mathrm{~mm}$ holes in the floor slab and epoxy-fix Y10 dowels at four dowels per square metre;

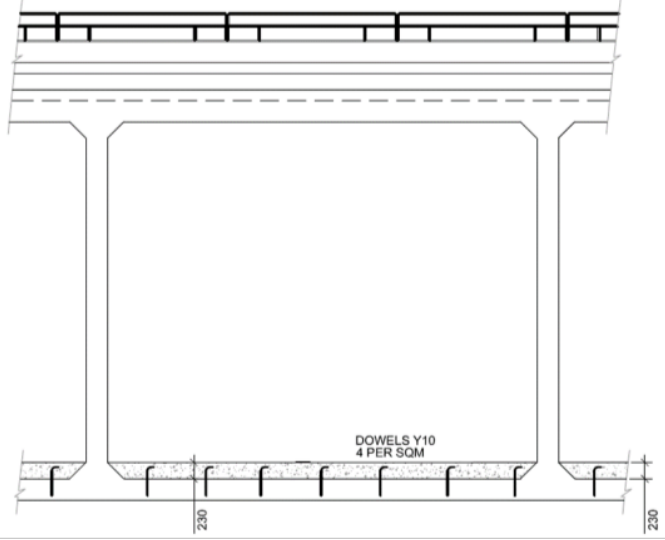

Figure 10: Construction of Strengthening Floor Slab

- Fix a top layer of Y16 bars at $200 \mathrm{~mm}$ centres longitudinally and $250 \mathrm{~mm}$ centres transversely;

- Cast 25MPa strength concrete, $230 \mathrm{~mm}$ thick;

- After wood floating the surface, create a surface Vjoint longitudinally every $3.0 \mathrm{~m}$;

- Cure the concrete properly for a minimum of 3 days in accordance to COLTO specifications. 


\subsubsection{Cleaning and Repair of Joints}

The joints on the top and sides at bridges B4752_2 and B4751 had to be repaired to prevent water and debris from entering the joints. This was done in accordance with the following methodology:

- On the deck of the bridges, close the road in half-width to accommodate traffic and allow continuous traffic flow;

- Remove a $50 \mathrm{~mm}$ wide strip of the chip and spray surfacing, approximately $25 \mathrm{~mm}$ on each side of the joint;

- Clean the joints thoroughly of any debris and old joint sealant by low-pressure water-jetting;

- Install a $16 \mathrm{~mm}$ backer cord about 50-60 $\mathrm{mm}$ deep in the roadway and $30 \mathrm{~mm}$ deep at the kerb and concrete verge;

- Seal kerb and concrete verge portion of the joints with a $6 \mathrm{~mm}$ deep approved highway silicon seal recessed $9 \mathrm{~mm}$ below the surface;

- Seal the joint on the chip and spray surfacing with asphaltic joint material (BJ binder), 50-60 mm deep and apply a crack seal "shoe" $50 \mathrm{~mm}$ wide. Lap this over the concrete seal;

- Cure the sealant properly. The silicone need to cure before the installation of asphaltic material for a period of approximately 15 days;

- Repair the $50 \mathrm{~mm}$ wide chip and spray surfacing along the joint where applicable.

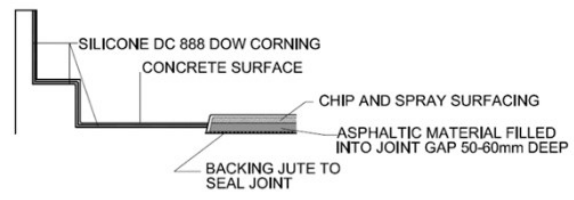

JOINT REPAIR LONG SECTION

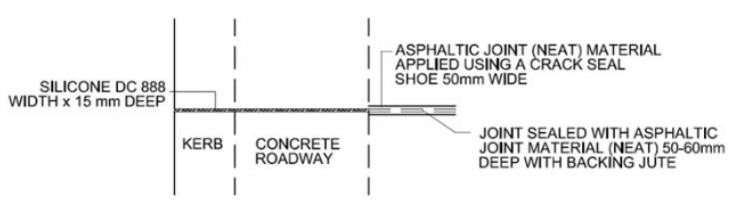

JOINT PLAN VIEW

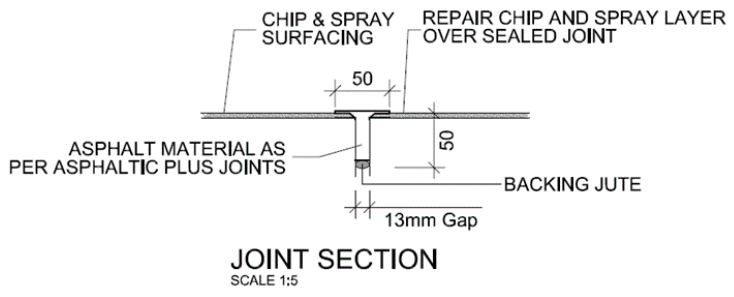

OVERLAP 50-100mm

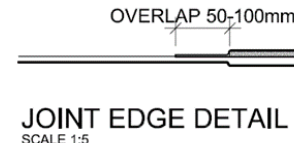

Figure 11: Joint Detail

\subsubsection{Repair of Spalling and Cracks in Piers, Abutments \& Kerbs}

Severe spalling and cracking in all structural elements were repaired in accordance with the following methodology:

- Mechanically remove all loose material and old concrete;

- Sand-blast any exposed reinforcing steel until shiny;

- Clean all surfaces to be repaired thoroughly by lowpressure water-jetting;

- Apply an approved cementitious bonding slurry to the surfaces to be repaired as well as an anti-corrosion primer to the cleaned reinforcing;

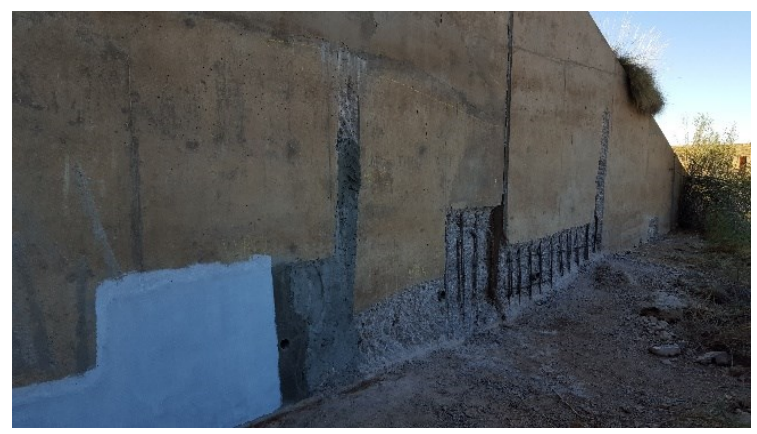

Figure 12: Repair of Spalling in Wing Wall of Bridge B4751

- Plaster re-profile the patches with an approved polymer modified repair mortar;

- Cure repaired surfaces with an approved spray-on curing compound.

\subsubsection{Protective coatings}

In order to protect the concrete against the harsh environmental conditions, a water repellent, surface impregnate application was applied to damaged and weathered surfaces. This was done in accordance with the following methodology:

- Clean concrete surfaces thoroughly by low-pressure water-jetting;

- Apply an approved silane coating to the manufacturer's specifications.

\subsection{Culverts}

The remedial measures to the 24 major culverts can be summarized as follows:

- Strengthening of deck slabs with carbon fibre strips (four culverts);

- Construction of apron slab and cut-off wall to mitigate erosion (one culvert);

- Strengthen crumbling walls by constructing new support walls (four culverts);

- Reconstruct fractured concrete wing walls and head walls (various culverts);

- Repair spalling and cracks in concrete structural elements (various culverts);

- Protective silane coating to deteriorating concrete surfaces (various culverts); 
- Removing vegetation overgrowth close to structures (various culverts).

\subsubsection{Strengthening of Deck Slabs}

In order to mitigate the sagging cracking noted in the culvert decks, carbon fibre strips were attached to the soffit of the decks in accordance with the following methodology:

- Clean the slab soffits and pier surfaces of all dirt, bird and insect nests with low-intensity water jetting;

- Prop the $2.4 \mathrm{~m}$ span decks at centre span position every $1.5 \mathrm{~m}$ using adjustable props with forcemeasurement equipment, applying the force equal to relieving the dead load of the deck and fill only;

- Prepare soffit surface by scabbling and water jet cleaning strips at $500 \mathrm{~mm}$ centres to receive epoxy adhesive compound for carbon fibre strips;

- Apply proprietary epoxy adhesive compound and $50 \mathrm{x}$ $1.2 \mathrm{~mm}$ carbon fibre with minimum $2800 \mathrm{MPa}$ tensile strength plates to the manufacturer's specifications;

- After epoxy has cured and hardened in accordance to the manufacturer's specifications, remove props;

- Epoxy crack-inject and seal all visible cracks larger than $0.5 \mathrm{~mm}$;

- Check and monitor all injected cracks for any changes.

\subsubsection{Construction of Apron Slab}

In order to mitigate downstream erosion, an apron slab was constructed at one culvert in accordance with the following methodology:

- Clear, level and fill the area underneath the apron slab with suitable rock fill (gabion mattresses);

- Dowel bars into side of invert slab;

- Construct apron slab and cut-off wall using $25 \mathrm{MPa}$ strength concrete reinforced with Y16 bars at $200 \mathrm{~mm}$ centres in both directions and with $30 \mathrm{~mm}$ cover;

- Cure the concrete in accordance with the COLTO specifications;

- Backfill around apron with rock fill (gabion mattresses) to natural levels.

\subsubsection{Construction of New Culvert Support Walls \& Invert Slab}

Where the internal walls of the culverts were in a very poor condition and and nearing collapse, new support walls with integrated bottom slabs were constructed in accordance with the following methodology:

- Clean the walls and invert slab of all dirt, bird and insect nests with low-intensity water jetting;

- Prop the deck slabs properly;

- Carefully scabble the walls and floor slabs to provide a rough surface. Clean all surfaces using high pressure water jetting. Due to the poor condition of the concrete at some of the culverts, the water jetting had to be done carefully as to not remove excessive volumes of concrete;

- Drill $12 \mathrm{~mm}$ holes in the floor slab for Y10 dowels and epoxy-fix dowels into position;
- Fix a layer of Y16 bars at $200 \mathrm{~mm}$ centres longitudinally and at $250 \mathrm{~mm}$ centres transversely;
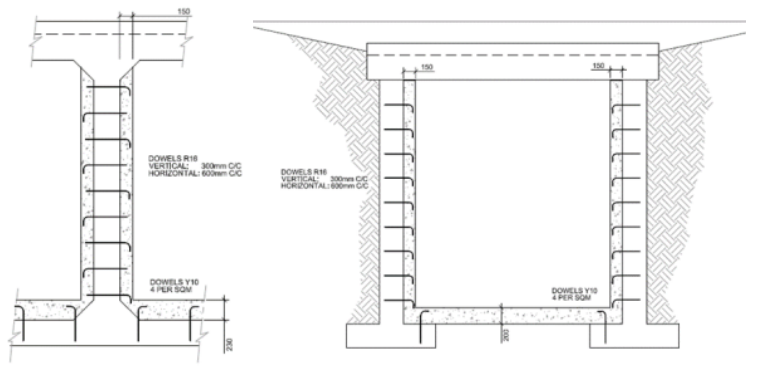

Figure 13: Construction of Support Walls and Invert Slab

- Cast 25MPa strength concrete, $150 \mathrm{~mm}$ thick against the old wall, integrated with an overlay slab at least $200 \mathrm{~mm}$ thick and with $30 \mathrm{~mm}$ cover to the reinforcing;

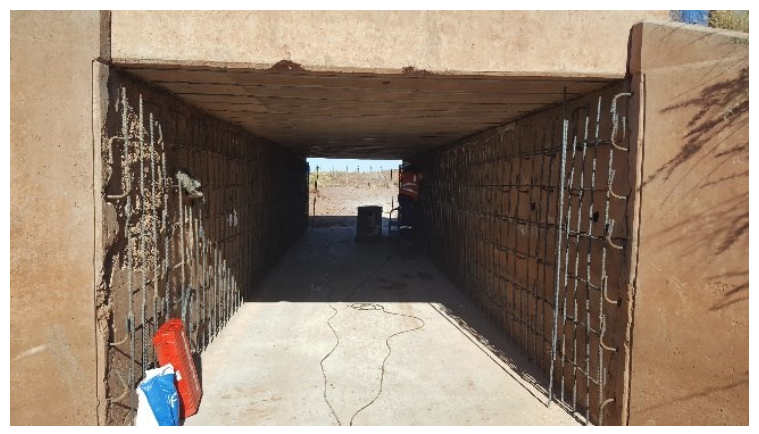

Figure 14: Steel Reinforcement for Support Walls

- After wood floating the surface of the floor slab, create a surface V-joint longitudinally every $3.0 \mathrm{~m}$.

- Cure the concrete for a minimum of 3 days in accordance to COLTO specifications.

The new support walls were constructed over the full internal height of the culvert between the top of the new invert slab and the soffit of the existing deck slab. In order to cast the walls, $110 \mathrm{~mm}$ diameter holes were drilled in the road surface through the pavement layers and culvert deck. The concrete was then poured through the holes. Vibration of the concrete was not possible and, in order to reduce the risk of 'honeycombing', a plasticiser was added to the mix. Only the top half of the internal walls were cast in this way, also in an effort to reduce the risk of 'honeycombing'.

\subsubsection{Reconstruction of Top of Wing- and Head Walls}

The top section of al large number of head- and wing walls were broken off. They were repaired in accordance with the following methodology:

- Remove all loose and broken concrete without damaging the existing reinforcement;

- Clean all surfaces using high-pressure water jetting; 

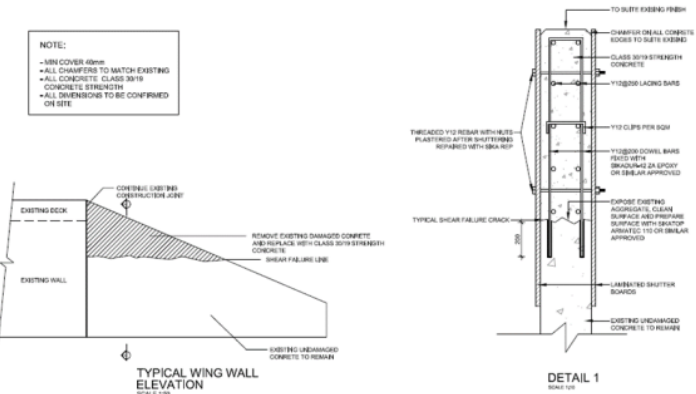

Figure 15: Wing Wall and Head Wall Repair

- Drill $12 \mathrm{~mm}$ holes in the existing concrete and epoxy fix Shape Code 38 Y10 dowels vertically and Y16 lacer bars in the horizontal positions of each face;

- The dowel bars should be doweled to a minimum depth of $200 \mathrm{~mm}$;

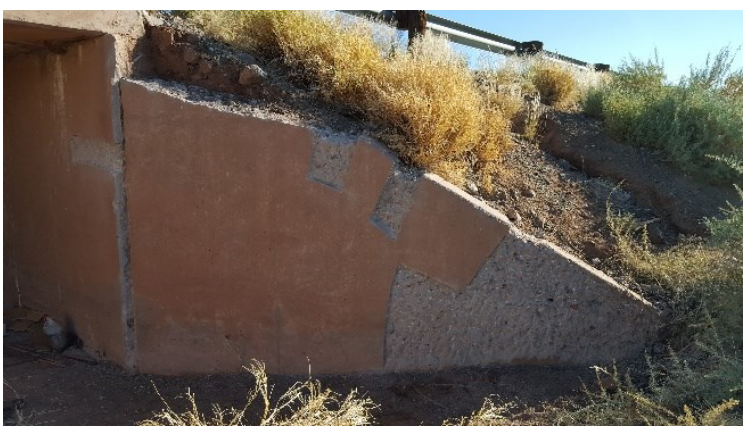

Figure 16: Top of Wing Wall prepared for Repairs

- Prepare the exposed concrete surface with an approved cementitious bonding slurry for joining to the new concrete segments;

- Set formwork in such a way as to tie in neatly with the existing structural members and cast $25 \mathrm{MPa}$ concrete;

- Cure the concrete for at least 3 days in accordance to COLTO specifications.

\subsubsection{Repair of Spalling and Cracks in Structural Elements}

Severe spalling and cracking in all structural elements were repaired in accordance with the following methodology:

- Mechanically remove all loose material and old concrete;

- Sand-blast any exposed reinforcing steel until shiny;

- Clean all surfaces to be repaired thoroughly by lowpressure water-jetting;

- Apply an approved cementitious bonding slurry to the surfaces to be repaired as well as an anti-corrosion primer to the cleaned reinforcing;

- Plaster re-profile the patches with an approved polymer modified repair mortar;

- Cure repaired surfaces with an approved spray-on curing compound.

\subsubsection{Protective coatings}

In order to protect the concrete against the harsh environmental conditions, a water repellent, surface impregnate application was applied to damaged and weathered surfaces. This was done in accordance with the following methodology:

- Clean concrete surfaces thoroughly by low-pressure water-jetting;

- Apply an approved silane coating to the manufacturer's specifications.

\section{Conclusion}

The outcomes of the rehabilitation project was satisfactory and the anticipated objectives were achieved. The following details are provided as the final project milestones added to the next 30-50 years' service life:

a) Strengthening and remedial work to three bridge structures successfully completed on the following work categories:

i. Strengthening of deck sections of box structure with carbon fibre strips;

ii. Strengthening of floor slabs of box structure with concrete overlays;

iii. Repair of the bridge joints;

iv. Repair spalling and cracks in the concrete piers $\&$ abutments;

v. Protective silane coating to deteriorating concrete surfaces;

vi. Repair spalling and cracks on some parapet kerbs.

b) Remedial work on 24 major culverts successfully completed within the following work categories:

i. Strengthening of deck slabs with carbon fibre strips;

ii. Construct apron slab and cut-off wall downstream to mitigate erosion problems;

iii. Strengthen crumbling head and wing walls by constructing new support head and wing walls and invert slabs;

iv. Reconstruct fractured parts of concrete wing walls and head walls;

v. Repair spalling and cracks in concrete structural elements;

vi. Protective silane coating to deteriorating concrete surfaces. 